\title{
SAMPLE VIEWS OF AFRICAN POST-GRADUATE STUDENTS \\ REGARDING ENGLISH AND THE AFRICAN LANGUAGES AS MEDIA OF EDUCATION IN AFRICAN SCHOOLS IN SOUTH AFRICA
}

\author{
Abram L Mawasha
}

Although African post-graduates recognise the importance of African languages in the education of African children in South Africa, most of them are of the opinion that English should not only be taught as a language from grade 1, but should also be preferred as the main language of instruction for African children from the outset of schooling. In the ensuing pilot study which involved 50 post-graduates, $68 \%$ expressed this opinion as against the rest who preferred a variety of other options.

The study comments on the implications of these findings for the new democratic language in education policy.

Hoewel die belangrikheid van Afrikatale in die onderwys van leerlinge wie se huistale dit is, deur nagraadse studente wat ook Afrikatale praat, erken word, meen die meeste van hulle dat Engels nie slegs as 'n taal onderrig moet word van graad 1 af nie, maar ook verkies behoort te word as die hooftaal van onderrig vir sulke leerlinge van die begin van hul skoolloopbaan af. In die loodsstudie wat onderneem is onder 50 nagraadse studente, het $68 \%$ hierdie mening uitgespreek.

Hierdie studie behandel die implikasies van hierdie bevindinge vir die nuwe demokratiese taal-in-onderwysbeleid.

\section{INTRODUCTION}

In white schools in South Africa, English and Afrikaans are the accepted media of education. Section 2 (i) (c) of the National Education Policy Act 39 of 1967 stipulates in part that:

the mother tongue, if it is English or Afrikaans, shall be the medium of instruction with gradual equitable adjustment to this principle of any existing practice at variance therewith.

(See White Paper on the Provision of Education in the Republic of South Africa, 1983: 37.) 
In African schools, however, the question as to which language to use - English or the African languages - is yet be resolved. According to available literature, the issue of the status and role of African languages as opposed to European languages as languages of learning dates as far back as 1658 (Verslag van die Werkkomittee, Tale en Taalonderrig, 1981: 14). No wonder the Interdepartmental Committee on Native Education (1935-1936) described the issue as a 'vexed question' (par 437, B., p. 83). The debate seems to centre around three areas:

(a) the linguistic capacity of African languages to carry Western-oriented education content which Africans have had to accept and adopt as a matter of practical necessity;

(b) the extent to which education through the medium of African languages can facilitate access to further education and training beyond the domain of the African language;

(c) the economic viability of African languages in work areas requiring Western educational expertise.

The Report of the Main Commission of the HSRC Investigation into Education: Provision of Education in the RSA (1981:142) recognises 'the heterogeneous and multilingual composition of the South African population (plural society)' and the right of speakers of African languages to develop and choose an $\mathrm{Ll}$ as medium of instruction at least 'for the duration of compulsory education'. The Report subtly hints at the advisability of returning to English or Afrikaans as a practical necessity 'to facilitate access to other or higher levels of education' (HSRC 1981: 143-144).

The National Education Policy Investigation on Language (1992) recognises the right of the parents 'to choose the medium of instruction ' for their children, but observes that

the underlying supposition seems to be that, although initial mother tongue instruction might be widely considered best for children, there are compelling reasons why many South African parents might prefer to opt for English (or Afrikaans) as medium of instruction from year one, even if it is not spoken at all at home, and that this choice should be respected and provided for (p. 40).

The ANC Policy Framework for Education and Training not only recommends language parity between English and Afrikaans on the one hand and the African languages on the other, but also proposes as a general principle

the right of the individual to choose which language or languages to study and use as a language of learning (medium of instruction).

(ANC 1994a: 62-63)

The Draft White Paper on Education and Training of the new Department of Education (Notice 1030, No 15974, 1994) acknowledges 'the right to language and culture' in South Africa and stipulates that: 
every person has the right to instruction in the language of his or her choice where this is reasonably practicable (p. 24).

Clause 3 of the Draft Constitution (Act 200 of 1993) stresses language parity and language rights for all citizens.

It seems the final word on the language in education debate that started around 1658 (see above) is yet to be spoken. It is for this and related reasons that the Department of Language Methodology, University of the North, has made the language in education debate a subject for instruction and research.

\section{AIM OF STUDY}

The aim of this study is to elicit views of post-graduate students at a Historically Black University (HBU) on the knotty question of English versus African languages in African schools in South Africa. Post-graduate students represent a core of the nation's active intelligentsia and for that reason they cannot be ignored when enlightened or informed opinion is sought on some major issue bearing on the development of a country and its people.

The Reconstruction and Development Programme (1994) seems to challenge African researchers and post-graduate students when it says:

development is not about delivering of goods to a passive citizenry. It is about active involvement and growing empowerment (p. 5).

This pilot study aims to respond to this challenge.

\section{DESCRIPTION OF TARGET RESEARCH GROUP}

The target research group comprised post-graduate students with

(a) a minimum academic qualification of a university degree with a language(s) as major(s);

(b) a post-graduate teachers' diploma with at least a qualification in Language Methodology (English, Afrikaans or an African Language); and who are

(c) currently engaged in post-graduate (second degree) studies with Language Education and Language Learning and Methodology as specialisation areas.

It was reasoned that data elicited from such a specialised group would represent

(a) opinion at the highest possible student level at a Historically Black University; 
(b) active thinking and debate at this academic (and professional) level;

(c) the type of information that education administrators may want to consider in planning education and training for a democratic South Africa;

(d) the extent to which reports that have heretofore addressed the subject are in fact representative of current academic (and professional) thinking among African postgraduate students.

The selection of the target group from a HBU was not based on race in the negative apartheid sense, but rather on

(a) relevance, i.e. what do African post-graduate students themselves think and feel about the subject of medium of education in their schools; and

(b) specialist training, i.e. all the research subjects were language educationists and therefore most qualified to express an opinion on the subject of language in education in schools.

\section{COLLECTION OF RESEARCH DATA}

The study was spread over a period of about 3 years. The research group comprised 50 postgraduates.

(a) Students were made aware of the available literature on the subject in a routine fashion as part of their studies. They were then asked to write an assignment in which they express a personal opinion on the subject.

(b) For purposes of research analysis, subjects were divided into male and female.

(c) They were further divided into part-time and full-time students (post-graduate programmes in Education at the University of the North make provision for part-time students).

(d) Assignments were read through routinely, but the personal opinion section was specifically targeted and carefully recorded as research data for subsequent analysis and write-up.

Research data collected in this way was perhaps even more authentic and reliable than data collected 'formally' by means of a questionnaire or a structured interview in that:

(a) it was provided spontaneously without any effort (in a research sense) at 'pleasing' the researcher or filling in the questionnaire 'correctly' to meet the needs or expectations of the researcher; 
(b) it was thought through carefully since it was presented in the context of an assignment written up for credit;

(c) there was no time pressure, i.e. to provide the data within a specified time frame with the researcher or an assistant waiting to collect the responses.

(d) In terms of the wording of the cue, it was truly an opinion of the respondent.

\section{FINDINGS}

The research data collected was quantified into percentages for ease of interpretation and comment. The following findings were recorded:

1. 20 male ( $40 \%$ ) and 14 female ( $28 \%$ ) respondents felt that English should not only be preferred as the main medium of instruction in African education from Sub A (Grade 1), but that it should be introduced as a subject from the outset of schooling and be retained throughout. These respondents, however, recognised the importance of indigenous languages in African education, especially in the pre- and primary school, and called for their retention as subjects.

2. 3 male $(6 \%)$ and 7 female $(14 \%)$ respondents were of the opinion that indigenous languages (rather than English) should be the preferred media of education in African schools. These respondents were, however, mindful of the

(a) lack of textbooks in African languages at this stage (i.e. the 1990s);

(b) reduced socio-economic status and role of indigenous languages vis-à-vis English (and Afrikaans);

(c) positive language attitudes in favour of English (over African languages) as a language of education both in South Africa and in the English-speaking world at large;

(d) time honoured myth that English has special linguistic qualities that make it 'superior' to the African languages.

The respondents were, however, in favour of English as a subject from pre-primary school upwards. They expressed some anxiety at the ineffective L2 teaching strategies currently in general operation in most African schools and called for a revision of these at two levels, viz at pre-service teacher education institutions and at in-service (INSET) training institutions.

3. 3 male (6\%) and 7 female (14\%) respondents considered that English can only be a viable medium of instruction if introduced at least around grade 5 . Two reasons for this standpoint were advanced: 
(a) At this stage in their schooling, African children are reasonably equipped to cope (albeit in a limited way) with instruction given through the medium of English.

(b) Some textbooks are available in African languages for learners to use to advantage at this stage.

Basically, these respondents favour the common language policy followed in most African schools which stipulates that $\mathrm{Ll}$ be used as medium of instruction up to and including grade 4, followed by a switch-over to English from grade 5 onwards.

4. Only one female respondent explicity expressed herself in favour of a bilingual education model in which both English and the African languages would be used side by side as parallel or dual media of instruction from the lower primary school upwards.

Further analysis of data revealed that all $34(68 \%)$ respondents who favoured the use of English as medium of instruction in African schools were full-time students, while the 10 (20 $\%$ ) who favoured the sole use of African languages and the $5(10 \%)$ who favoured the initial use of African languages followed by a switch over to English and the one (2\%) respondent who favoured a bilingual model were all part-time students.

\section{INTERPRETATION OF RESEARCH FINDINGS}

If this pilot study is taken as a reliable indicator of informed opinion (i.e. of post- graduate students), the following body of opinion could be extrapolated:

Although many informed Africans (32\%) accept the viability of African languages as media of instruction, especially at the early stages of education, more than twice as many (68\%) still prefer English (i.e. in the 1990s). If this interpretation is taken as a valid indicator, it could be used to explain (in part at least) why the demise of apartheid in education was followed immediately by a surge of African pupils to traditionally White English medium schools throughout South Africa despite the high costs involved in placement in such schools. The myth of equating the English language with quality education seems to persist, despite language parity enshrined in Clause 3 of the new democratic Constitution.

Practical teaching experience in African education seems to influence opinion on the status and role of indigenous languages versus English (and Afrikaans) as media of instruction. All the 16 out of $50(32 \%)$ respondents who favoured the use of African language as media, partmedia, or parallel media of instruction were part-time students i.e. practising educators, while the rest ( 34 out of 50 or $68 \%$ ) who favoured the use of English were full-time students, i.e. educators with no practical classroom experience. It seems that most practising educators in African education are aware that 
(a) in practice many African educators code switch routinely from English to an African language in routine content-subject presentation to facilitate comprehension and to speed up progress through the syllabus;

(b) many African teachers often find it necessary to resort to an African language where their personal facility in English as classroom language falters;

(c) in routine content-subject presentation, the suspicion surrounding the use of an African language in education, i.e that it tends to lower the standard of African education compared to that of White education, either does not arise, or if it does, it is simply ignored. A teacher code-switches to deal with what he considers practical educational problems bearing on the understanding of a particular subject content or concept, as a matter of need. Whether those learners with adequate control of English or their parents who might be adherents of the elitist English model as norm for sterling education accept this strategy as viable or not is a separate issue altogether.

The significance of this interpretation for the language educationist is that if multilingualism and its attendant code switching or even code mixing occurred routinely up till now in African education to facilitate comprehension and internalisation of subject content matter (albeit done 'unofficially'), the new language policy of multilingualism may, in time, catch on, especially in predominantly African classrooms with little or no persuasion. It will be like 'officialising' what is routinely done 'unofficially', or rendering a de facto situation de jure.

One problem remains still unanswered: how will the policy of multiligualism be realised in those schools that enrol African learners while the teachers are monolingual English speakers? Will the teachers be 'forced' to learn African languages in order to actualise the policy of multilingualism, or will the African learners 'sacrifice' their mother tongue and all that goes with it, viz God-given cultural heritage, cognitive and affective advantages, selfperception, personality development, etc.?

Regarding the research data: if the manner in which responses were actually worded is analysed in some detail, these responses seem to reveal that African post-graduate students who are yet to gain practical classroom experience feel that African education will not only be better off if presented through the medium of English, but also that English as medium of instruction should be introduced right from the outset of schooling. The following two sample responses suggest no less:

The child should be introduced to the language of wider communication (English) right from the onset. This is important in that one does not remain with the problem of facing basic language requirement at a later stage.

If English is introduced immediately at sub A, the child is going to be fluent and have a good control of the language. In other words, the child is going to achieve and progress in future because language will not be his problem (sic). 
It is important, however, to point out that opinions of this nature are not always grounded on sound pedagogy. The following two sample responses seem to support this possibility:

Using straight for English option will in a way decrease apartheid in that people will be put in their rightful place at work. People who are expertise will be the one to see to it that the option is implemented (sic).

Most Black parents and teachers as well as learners seem to prefer the use of English in their schools as medium of instruction. The reason being that it is a language of prestige, it can carry content effectively, it is an international language and historically does not seem to have an evil in it. Mother tongue is seen as inferior and is associated with the Bantu Education Act of 1953, while Afrikaans is regarded as a language of the oppressor.

\section{CONCLUSION}

The Department of Language Methodology at the University of the North is monitoring the debate on language in education very closely, especially the possible tensions between Clause 3 of our democratic Constitution (and the language policy that flows from it) and the seeming preference for traditionally White English medium schools by many African parents (and pupils too!), especially the elite and the intelligentsia. An interesting question is whether socio-political transformation of South Africa will lead to African language and culture being seen as an important component of education and training, or will knowing continue to be equated with English language proficiency?

\section{REFERENCES}

ACT NO. 200. 1993: Constitution of the Republic of South Africa. Cape Town: Government Printers.

ANC: 1994a. Draft policy framework for education and training.

ANC: 1994b. The reconstruction and development programme document.

ANC: 1994c. Implementation plan for education and training.

APPEL, R AND P MUYSKEN. 1987. Language contact and bilingualism. London: Edward Arnold.

CAPE OF GOOD HOPE, REPORT OF COMMISSION ON NATIVE EDUCATION. 1919. Cape Town: Government Printers,

DEPARTMENT OF EDUCATION. 1994. White Paper on Education and Training in Democratic South Africa. Pretoria: Ministry of Education. 
HUMAN SCIENCES RESEARCH COUNCIL. 1981a. Report of the Main Committee on the investigation into education: provision of education in the RSA. Pretoria: HSRC.

HUMAN SCIENCES RESEARCH COUNCIL. 1981b. Verslag van die Werkkomitee: Tale en Taalonderrig. Pretoria: HSRC.

MALHERBE, EG. 1943. The bilingual School. Johannesburg: CNA.

NATIONAL EDUCATION POLICY INVESTIGATION: LANGUAGE. 1992. Cape Town: Oxford University Press/NECC.

REPUBLIC OF SOUTH AFRICA. 1983. White Paper on the Provision of Education in the Republic of South Africa. Pretoria: Government Printer.

UNION OF SOUTH AFRICA: 1936. Report of the Interdepartmental Committee on Native Education, 1935-1936. Cape Town: Government Printer, 1936.

UNION OF SOUTH AFRICA. 1951. Report of the Commission on Native Education, 1949-1951. Pretoria: Government Printer. U.G. No 53/1951. 